\title{
XRCC1 variants do not represent a risk for dermatomyositis and systemic lupus erythematosus in Bulgarian patients
}

Zornitsa Kamenarska ${ }^{1}$, Maria Hristova², Rumyana Dodova ${ }^{3}$, Anton Vinkov ${ }^{4}$, Radka Kaneva³, Joana Pozharashka ${ }^{1}$, Lyubomir Dourmishev ${ }^{1 凶}$

\begin{abstract}
Introduction: Systemic lupus erythematosus (SLE) and dermatomyositis (DM) share a similar pathogenesis, and genetic, hormonal, and environmental factors are known to trigger the autoimmune process. The X-ray repair cross-complementing genes (XRCC1 and $\mathrm{XRCC}_{3}$ ) are known to play a central role in mammalian DNA repair processes. Evidence suggests that impaired DNA repair efficiency is implicated in the development of autoimmune diseases. This case-control study investigates the association between the XRCC 1 Arg194Trp (C>T) and Arg399GIn (G>A) polymorphisms and the susceptibility to DM and SLE in Bulgarian patients.

Methods: Altogether 88 patients, 55 with SLE and 33 with DM, and 94 unrelated healthy controls were included in this study.

Results: None of the polymorphisms showed an association with SLE, DM, or their clinical parameters. The allele and genotype frequency of the two single nucleotide polymorphisms was similar to those found in other healthy Caucasian populations.

Conclusions: Our results indicate that the XRCC 1 rs1799782 Arg194Trp and rs25487 Arg399Gln polymorphisms do not play a role in the susceptibility to SLE and DM.
\end{abstract}

Keywords: $\mathrm{XRCC}_{1}$, polymorphisms, risk, dermatomyositis, systemic lupus erythematosus

Received: 8 November 2018 | Returned for modification: 12 July 2019| Accepted: 29 October 2019

\section{Introduction}

Systemic lupus erythematosus (SLE) is a chronic inflammatory disease that belongs to the group of autoimmune connective tissue diseases and affects multiple organs and systems (1), whereas dermatomyositis (DM) is a rare idiopathic inflammatory myopathy with a specific skin syndrome (2). Both SLE and DM are triggered by similar genetic, hormonal, and environmental factors.

An impaired DNA repair process is considered to represent a major risk factor for autoimmune disease susceptibility. There are two main mechanisms involved in single-stranded DNA damage repair: base excision repair (BER) and nucleotide excision repair (3). The X-ray repair cross-complementing gene 1 (XRCC1) belongs to the BER pathway (4). Some XRCC proteins were found at the DNA damage sites, which confirms their role as factors in the incidence of various autoimmune disorders (5-7).

There are two common polymorphisms in the XRCC1 gene
(Arg194Trp exon 6, C>T, rs1799782 and Arg399Gln exon 10, G>A, rs25487) that lead to amino acid replacement. Although the precise effects of these polymorphisms remain unknown, it is suggested that amino acid changes at the preserved regions may alter their function (8). Changes in protein biochemistry lead to the assumption that the variant alleles may reduce the kinetics of the repair process, thus contributing to disease susceptibility (9).

This study investigates the role of XRCC1 polymorphisms as risk factors for the development of DM and SLE in Bulgarian patients and defines their contribution to increased risk.

\section{Materials and methods}

\section{Patients and controls}

The patient group consisted of 33 patients with DM who fulfilled the modified classification criteria of Targoff et al. (10) and 55

Table 1 | Demographic and clinical data.

\begin{tabular}{|c|c|c|c|c|}
\hline Parameters & \multicolumn{2}{|c|}{ DM } & \multicolumn{2}{|c|}{ SLE } \\
\hline $\begin{array}{l}\text { Demographic } \\
\text { Female/male } \\
\text { Mean age } \pm \text { SD }\end{array}$ & \multicolumn{2}{|c|}{$\begin{array}{c}20 / 13 \\
52 \pm 14.7 \text { years }\end{array}$} & \multicolumn{2}{|c|}{$\begin{array}{c}45 / 10 \\
40 \pm 12.4 \text { years }\end{array}$} \\
\hline Clinical, $n(\%)$ & $\begin{array}{c}\text { Cutaneous disease } \\
\text { Muscle weakness } \\
\text { Elevated muscle enzymes } \\
\text { EMG findings } \\
\text { Photosensitivity } \\
\text { Autoantibodies }\end{array}$ & $\begin{array}{l}25(75.8) \\
27(81.8) \\
19(57.6) \\
19(57.6) \\
19(57.6) \\
9(27.3)\end{array}$ & $\begin{array}{c}\text { Malar rash } \\
\text { Discoid rash } \\
\text { Arthritis } \\
\text { Oral ulcer } \\
\text { Photosensitivity } \\
\text { Serositis } \\
\text { Renal disease } \\
\text { Neurological disease } \\
\text { Hematological disease } \\
\text { Immunological disease } \\
\text { ANA }\end{array}$ & $\begin{array}{c}33(60.0) \\
11(20.0) \\
38(69.1) \\
3(5.5) \\
31(56.4) \\
14(25.5) \\
55(100.0) \\
11(20.0) \\
24(43.6) \\
35(63.6) \\
41(74.5)\end{array}$ \\
\hline
\end{tabular}


patients with SLE who fulfilled the revised American College of Rheumatology (ACR) criteria (11).

Among the DM patients, 20 were female and 13 male. Patients' age varied from 18 to 82 years, with a mean age of 52 . SLE patients were predominantly female (45), and only 10 male patients were included. The mean age of the SLE group was 40 with a range between 15 and 78 years. The follow-up was conducted at the Department of Dermatology and Department of Nephrology, Medical University of Sofia and at the Department of Nephrology, Ministry of Interior Hospital in Sofia for a mean period of 10 years. Ninetyfour healthy sex-, age-, and ethnicity-matched controls were selected from the BioBank of the Molecular Medicine Center and National Genetic Laboratory. Table 1 presents their demographic and clinical data.

The investigation presented in this article was performed in line with the Declaration of Helsinki for research involving humans and was approved by the local ethics committee. Venous blood samples were drawn for DNA isolation after written informed consent signed by all participants.

\section{Genetic analysis}

DNA was extracted using the Chemagen DNA purification kit (Chemagen AG, San Francisco, USA).

The analysis of the polymorphisms was performed using the TaqMan genotyping assay, and the allele calling was carried out with Applied Biosystems 7500 software version 2.0.5.

Catalogue primers ordered by Thermo Fisher Scientific were used for the analysis. The rs1799782 context sequence (VIC/FAM) is TCACCTGGGGATGTCTTGTTGATCC[A/G]GCTGAAGAAGAGAGCCCCCGGCCTC (https://www.thermofisher.com/order/genome-database/details/genotyping/C__11463404_10?CID=\&ICID=\&subty pe=) and the rs25487 context sequence (VIC/FAM) is GGGTTGGCGTGTGAGGCCTTACCTC[C/T]GGGAGGGCAGCCGCCGACGCATGCG (https://www.thermofisher.com/order/genome-database/ details/genotyping/C__-_622564_10?CID = \&ICID=\&subty pe=). The TaqMan reaction was performed according to the instructions provided by Thermo Fisher Scientific in a volume of $5 \mu$ containing $2.5 \mu \mathrm{l} 2 \mathrm{X}$ TaqMan ${ }^{\circledR}$ Master Mix, o.12 $\mu \mathrm{l}$ 40X Assay Working Stock, o.88 $\mu \mathrm{l} \mathrm{dH2O}$, and $1.5 \mu \mathrm{l}$ DNA template (10 $\mathrm{ng} / \mu \mathrm{l})$. The amplification conditions were initial denaturation at $95^{\circ} \mathrm{C}$ for $10 \mathrm{~min}$, followed by 40 cycles of $95^{\circ} \mathrm{C}$ for $15 \mathrm{~s}$ and $60^{\circ} \mathrm{C}$ for $60 \mathrm{~s}$. Internal positive controls were used to confirm the results.

\section{Statistical analysis}

Statistics were calculated using SPSS 22.0 software (SPSS Inc,

Chicago, USA). The test for Hardy-Weinberg equilibrium was performed using chi-square $\left(x^{2}\right)$ statistics. Changes in allele frequencies in DM, SLE cases, and controls were compared using Fisher's exact test, and their significance was expressed as $p$-value and odds ratios (OR) with exact 95\% confidence intervals (CI).

\section{Results}

Altogether 88 patients were analyzed: 33 with DM and 55 with SLE. Women prevailed in both groups, which is typical for autoimmune diseases. The mean age was lower among patients with SLE than among patients with DM (40 vs. 52, Table 1). Arg399Gln did not show any association with the development of the diseases, although the major genotype Arg/Arg is more frequent among patients with DM compared to controls (48.5\% vs. 38.4\%, Table 2).

Arg194Trp did not show any association with the development of DM and SLE. The major genotype Arg/Arg has a frequency of about $80 \%$ in all groups (Table 2). The Arg399Gln polymorphisms did not show any association with the ACR criteria for SLE or the DM criteria (Tables 3, 4). The Arg194Trp polymorphisms did not show any association with the ACR criteria (Table 5). Due to its low frequency, the association with the DM clinical parameters was not studied.

\section{Discussion}

XRCC1 is a DNA repair protein that makes complexes with various polymerases and ligases to repair DNA single-strand breaks (1214). Thus, it seems logical to hypothesize that individuals with impaired XRCC1 function would show an elevated risk of developing diseases and their clinical manifestations.

Table 2 | Genotype and allele frequencies of the XRCC1 rs1799782 C/T (Arg194Trp) and rs25487 G/A (Arg399GIn) polymorphisms among patients with dermatomyositis (DM), systemic lupus erythematosus (SLE), and controls.

\begin{tabular}{lccc}
\hline Genotype & DM & SLE & Controls \\
\hline rs1799782 C/T (Arg194Trp) & & & \\
CC (Arg/Arg) & $25(83.3 \%)$ & $44(80.0 \%)$ & $83(88.3 \%)$ \\
CT (Arg/Trp) & $1(3.4 \%)$ & $1(1.8 \%)$ & $1(1.1 \%)$ \\
TT (Trp/Trp) & $4(13.3 \%)$ & $10(18.2 \%)$ & $10(10.6 \%)$ \\
C (Arg) & $51(85.0 \%)$ & $89(80.9 \%)$ & $167(88.8 \%)$ \\
T (Trp) & $9(15.0 \%)$ & $21(19.1 \%)$ & $21(11.2 \%)$ \\
$p$ value & 0.5 & 0.2 & \\
\hline rs25487 G/A (Arg399GIn) & & & \\
GG (Arg/Arg) & $16(48.5 \%)$ & $19(35.2 \%)$ & $35(38.4 \%)$ \\
GA (Arg/Gln) & $10(30.3 \%)$ & $24(44.4 \%)$ & $42(46.2 \%)$ \\
AA (Gln/Gln) & $7(21.2 \%)$ & $11(20.4 \%)$ & $14(15.4 \%)$ \\
G (Arg) & $42(63.6 \%)$ & $62(57.4 \%)$ & $112(61.5 \%)$ \\
A (Gln) & $24(36.4 \%)$ & $46(42.6 \%)$ & $70(38.5 \%)$ \\
$p$ value & 0.3 & 0.9 & \\
\hline
\end{tabular}

Table 3 | Comparison between rs25487 G/A (Arg399GIn) alleles and genotypes and the American College of Rheumatology criteria for systemic lupus erythematosus.

\begin{tabular}{|c|c|c|c|c|}
\hline Genotype & $\mathrm{GG}(n=19)$ & $\mathrm{GA}(n=24)$ & $\mathrm{AA}(n=11)$ & $p$ value \\
\hline Malar rash & $12(63.2 \%)$ & $13(54.2 \%)$ & $70(73.6 \%)$ & 0.7 \\
\hline Discoid rash & $2(10.5 \%)$ & $5(20.8 \%)$ & $2(18.2 \%)$ & 0.5 \\
\hline Photosensitivity & $10(52.6 \%)$ & $12(50.0 \%)$ & $7(63.6 \%)$ & 1 \\
\hline Oral ulcer & $0(0.0 \%)$ & $2(8.3 \%)$ & $1(9.1 \%)$ & 0.3 \\
\hline Arthritis & $12(63.2 \%)$ & $18(75.0 \%)$ & $7(63.6 \%)$ & 0.5 \\
\hline Serositis & $4(21.1 \%)$ & $6(25.0 \%)$ & $3(27.3 \%)$ & 0.7 \\
\hline Renal disease & $19(100.0 \%)$ & $24(100.0 \%)$ & $11(100.0 \%)$ & 1 \\
\hline Neurological disease & $6(31.6 \%)$ & $4(16.7 \%)$ & $1(9.1 \%)$ & 0.2 \\
\hline Hematological disease & $9(47.4 \%)$ & $8(33.3 \%)$ & $5(45.5 \%)$ & 0.6 \\
\hline $\begin{array}{l}\text { Immunological disease (Anti-dsDNA, } \\
\text { Anti-Sm, Anti-phospholipid) }\end{array}$ & $11(57.9 \%)$ & $16(66.7 \%)$ & $8(72.7 \%)$ & 0.6 \\
\hline ANA & $14(73.7 \%)$ & $17(70.8 \%)$ & $8(72.7 \%)$ & 1 \\
\hline
\end{tabular}

ANA = antinuclear antibodies. 
Table 4 | Comparison between the rs25487 G/A (Arg399GIn) alleles and genotypes and dermatomyositis clinical parameters.

\begin{tabular}{|c|c|c|c|c|}
\hline Genotype & $\mathrm{GG}(n=16)$ & $\mathrm{GA}(n=10)$ & $\mathrm{AA}(n=7)$ & $p$ value \\
\hline Muscle weakness & $15(93.8 \%)$ & $5(50.0 \%)$ & $7(100.0 \%)$ & 0.2 \\
\hline Photosensitivity & $9(56.3 \%)$ & $7(70.0 \%)$ & $3(42.9 \%)$ & 0.6 \\
\hline Elevated muscle enzymes & $10(62.56 \%)$ & $4(40.0 \%)$ & $5(71.4 \%)$ & 0.7 \\
\hline EMG findings & $8(50.0 \%)$ & $4(40.0 \%)$ & $7(100.0 \%)$ & 0.5 \\
\hline Cutaneous disease & $14(87.5 \%)$ & $5(50.0 \%)$ & $6(85.7 \%)$ & 0.2 \\
\hline Antibodies & $5(31.3 \%)$ & $1(10.0 \%)$ & $3(42.9 \%)$ & 0.7 \\
\hline
\end{tabular}

EMG=electromyography.

Table 5 | Comparison between the rs1799782 C/T (Arg194Trp) alleles and genotypes and the American College of Rheumatology criteria for systemic lupus erythematosus.

\begin{tabular}{|c|c|c|c|c|}
\hline Genotype & $\mathrm{CC}(n=44)$ & $\mathrm{CT}(n=1)$ & $\mathrm{TT}(n=10)$ & $p$ value \\
\hline Malar rash & $26(59.1 \%)$ & $0(0.0 \%)$ & $70(70.0 \%)$ & 1 \\
\hline Discoid rash & $10(22.7 \%)$ & $0(0.0 \%)$ & $1(10.0 \%)$ & 0.4 \\
\hline Photosensitivity & $27(61.4 \%)$ & $0(0.0 \%)$ & $4(40.0 \%)$ & 0.2 \\
\hline Oral ulcer & $3(6.8 \%)$ & $0(0.0 \%)$ & $0(0.0 \%)$ & 1 \\
\hline Arthritis & $31(70.5 \%)$ & $1(75.0 \%)$ & $6(60.0 \%)$ & 0.7 \\
\hline Serositis & $12(27.3 \%)$ & $1(25.0 \%)$ & $1(10.0 \%)$ & 0.7 \\
\hline Renal disease & $44(100.0 \%)$ & $1(100.0 \%)$ & $10(100.0 \%)$ & 1 \\
\hline Neurological disease & $9(20.5 \%)$ & $0(0.0 \%)$ & $2(20.0 \%)$ & 1 \\
\hline Hematological disease & $18(40.9 \%)$ & $1(100.0 \%)$ & $5(50.0 \%)$ & 0.5 \\
\hline $\begin{array}{l}\text { Immunological disease (Anti-dsDNA, } \\
\text { Anti-Sm, Anti-phospholipid) }\end{array}$ & $27(61.4 \%)$ & $0(0.0 \%)$ & $7(70.0 \%)$ & 1 \\
\hline ANA & $32(72.7 \%)$ & $1(100.0 \%)$ & $8(80.0 \%)$ & 0.7 \\
\hline
\end{tabular}

ANA = antinuclear antibodies.

The frequency of the Arg399Gln genotype in the Bulgarian population is close to that found in the Polish population (15). The frequency of the minor allele $(38.5 \%)$ is in the range found for Caucasian populations $(15,16)$. A recent meta-analysis showed that Arg399Gln might play a role in susceptibility to SLE in the Asian population, but its role in the Caucasian population is still disputable (17). To date there have been two studies concerning the Caucasian population, which showed inconsistent results (15, 16). The Gln/Gln + Arg/Gln genotypes and the $399 \mathrm{Gln}$ allele were found associated with SLE in Polish patients, and the Gln/Gln + Arg/Gln genotypes were also found associated with malar rash and photosensitivity (15). Similar to our results, no association was found with susceptibility to SLE in Brazilian patients, but the XRCC1Arg399Gln was found associated with a higher prevalence of anti-dsDNA antibodies in sera. The concomitant presence of XRCC1Arg399Gln with other DNA repair polymorphic sites was associated with increased prevalence of nervous system pathology and antiphospholipid syndrome (16). Our results and the results obtained by other authors suggest that XRCC1Arg399Gln is not an independent factor in susceptibility to SLE in the Caucasian population, but it may confer a risk in combination with other DNA repair polymorphic sites.

The frequency of $399 \mathrm{Gln} / \mathrm{Gln}+\mathrm{Gln} / \mathrm{Arg}$ was higher among Taiwanese Han Chinese SLE patients, but the differences were not statistically significant. This functional single nucleotide polymorphism (SNP) was associated with malar rash, discoid rash, photosensitivity, antinuclear antibody, hematologic manifestations and joint involvement (18).

Interestingly, it was the 399Arg/Arg genotype and the Arg allele that were related to SLE and malar rash in Iranian patients (19). Such discrepancies are explained by the fact that autoimmune diseases are complex and multifactorial and are triggered by the interplay of both genetic and environmental causes. Fur- thermore, a different association was reported between XRCC1 gene polymorphisms and cancer in various ethnic groups, which suggests that the interactions between various environmental factors and genes may differ (20). Diversity in the clinical picture and some demographic factors can also lead to inconsistent results.

The Arg194Trp allele and genotype frequency was also similar in all groups. The frequency of the minor allele (11.2\%) is comparable with previous data for Caucasian populations (21). Our results support the findings that there is no significant association between this polymorphism and the autoimmune diseases in different genetic models $(17,22)$. Despite this, the $194 \operatorname{Trp} / \operatorname{Trp}$ genotype and the Trp allele have been related to discoid rash, anti-DN, and anti-Scl7o in Brazilian patients (21). The allele frequencies of Arg194Trp have been correlated with detectable autoantibodies and damage to the hematological system in Chinese Han SLE patients (23). The results suggest that this polymorphism may have a disease-modifying role in some populations.

\section{Conclusions}

Our results could not confirm the independent role of the XRCC1 SNPs to the susceptibility and clinical course of DM and SLE in Bulgarians. The major drawback of our study is the limited number of patients and controls, which affects the statistical significance of the results. Further studies in a larger cohort are needed to elucidate the role of these two polymorphisms for susceptibility and clinical manifestations of SLE and DM.

\section{Acknowledgments}

This work was funded by Grant - 2017 of Medical University-Sofia (contract 115, project 8519/2016). 


\section{References}

1. Kamenarska Z, Hristova M, Vinkov A, Dourmishev L. Monoclonal antibodies drugs for the treatment of systemic lupus erythematosus. Folia Med. 2015;57: 89-92.

2. Dourmishev L. The inflammatory myopathies with cutaneous involvement: from diagnosis to therapy. Folia Med. 2017;59:7-13.

3. Svilar D, Goellner EM, Almeida KH, Sobol RW. Base excision repair and lesiondependent subpathways for repair of oxidative DNA damage. Antioxid Redox Signal. 2011;14:2491-507.

4. Caldecott KW. XRCC 1 and DNA strand break repair. DNA Repair (Amst). 2003;2: 955-69.

5. Takeda Y, Dynan WS. Autoantibodies against DNA double-strand break repair proteins. Front Biosci. 2001;6:D1412-22.

6. Lee KJ, Dong X, Wang J, Takeda Y, Dynan WS. Identification of human autoantibodies to the DNA ligase IV/XRCC4 complex and mapping of an autoimmune epitope to a potential regulatory region. J Immunol. 2002;169:3413-21.

7. Tajouri L, Mellick AS, Ashton KJ, Tannenberg AE, Nagra RM, Tourtellotte WW, et al. Quantitative and qualitative changes in gene expression patterns characterize the activity of plaques in multiple sclerosis. Brain Res Mol Brain Res. 2003; 119:170-83.

8. Trabulus S, Guven GS, Altiparmak MR, Batar B, Tun O, Yalin AS, et al. DNA repair XRCC 1 Arg399G In polymorphism is associated with the risk of development of end-stage renal disease. Mol Biol Rep. 2012;39:6995-7001.

9. Liu F, Li B, Wei Y, Yan L, Wen T, Zhao J, et al. XRCC1 genetic polymorphism Arg$399 \mathrm{GIn}$ and hepatocellular carcinoma risk: a meta-analysis. Liver Int. 2011;31: 802-9.

10. Targoff IN, Miller FW, Medsger TA Jr, Oddis CV. Classification criteria for the idiopathic inflammatory myopathies. Curr Opin Rheumatol. 1997;9:527-35.

11. Hochberg MC. Updating the American College of Rheumatology revised criteria for the classification of systemic lupus erythematosus. Arthritis Rheum. 1997;40:1725.

12. Kubota Y, Nash RA, Klungland A, Schär P, Barnes DE, Lindahl T. Reconstitution of DNA base excision-repair with purified human proteins: interaction between DNA polymerase beta and the XRCC1 protein. EMBO J. 1996;15:6662-70.

13. Caldecott KW, Aoufouchi S, Johnson P, Shall S. XRCC1 polypeptide interacts with DNA polymerase beta and possibly poly (ADP-ribose) polymerase, and DNA ligase III is a novel molecular "nick-sensor" in vitro. Nucleic Acids Res. 1996;24: 4387-94.
14. Masson M, Niedergang C, Schreiber V, Muller S, Menissier-de Murcia J, de Murcia G. XRCC 1 is specifically associated with poly(ADP-ribose) polymerase and negatively regulates its activity following DNA damage. Mol Cell Biol. 1998;18: 3563-71.

15. Warchot T, Mostowska A, Lianeri M, Lącki JK, Jagodziński PP. XRCC1 Arg399Gln gene polymorphism and the risk of systemic lupus erythematosus in the Polish population. DNA Cell Biol. 2012;31:50-6.

16. Bassi C, Xavier D, Palomino G, Nicolucci P, Soares C, Sakamoto-Hojo E, et al. Efficiency of the DNA repair and polymorphisms of the XRCC $1, X^{X R C C_{3}}$ and XRCC DNA repair genes in systemic lupus erythematosus. Lupus. 2008;17:988-95.

17. Zhang MY, Yang XK, Lv TT, Wu J, Xu SZ, Wang JB, et al. Meta-analysis of associations between XRCC 1 gene polymorphisms and susceptibility to systemic lupus erythematosus and rheumatoid arthritis. Int J Rheum Dis. 2018;21:179-85.

18. Lin YJ, Wan L, Huang CM, Chen SY, Huang YC, Lai CH, et al. Polymorphisms in the DNA repair gene $\mathrm{XRCC}_{1}$ and associations with systemic lupus erythematosus risk in the Taiwanese Han Chinese population. Lupus. 2009;18:1246-51.

19. Salimi S, Mohammadoo-Khorasani M, Tabatabai E, Sandoughi M, Zakeri Z, Naghavi A. XRCC1 Arg399GIn and Arg194Trp polymorphisms and risk of systemic lupus erythematosus in an Iranian population: a pilot study. Biomed Res Int. 2014;2014:492956.

20. Hung RJ, Hall J, Brennan P, Boffetta P. Genetic polymorphisms in the base excision repair pathway and cancer risk: a HuGE review. Am J Epidemiol. 2005;162: 925-42.

21. Peruzzato FS. [A influencia do polimorfismo Arg194Trp no gene que codifica a proteina de reparo de DNA XRCC 1 em pacientes com lupus eritematoso sistemico]. Universidade Federal do Rio Grande do Sul, Porto Alegre, Brazil; 2010. Portuguese.

22. Peng M, Zhou X, Ding X, Wei L, Zhao Y, Zhu T, et al. Association of XRCC 1 Arg $399 \mathrm{GIn}$ and Arg194Trp polymorphisms with susceptibility to multiple autoimmune diseases: a meta-analysis. Rheumatol Int. 2017;37:435-444.

23. Zhang M, Qi M, Che DF, Guan HH, Hu WX, Deng DQ. Correlation between single nucleotide polymorphism of the DNA repair gene XRCC1 and systemic lupus erythematosus. Chin J Clin Lab Sci. 2011;29:115-7. 